\title{
Synthesis, COX-1/2 inhibition and antioxidant activities of new oxicam analogues designed as potential chemopreventive agents*
}

\author{
Berenika Szczęśniak-Sięga ${ }^{\circledR 凶}$, Katarzyna Gębczak², Tomasz Gębarowski² and \\ Jadwiga Maniewska ${ }^{\circledR}$
}

1Department of Chemistry of Drugs, Wroclaw Medical University, Wrocław, Poland; 2Department of Basic Medical Science, Wroclaw Medical University, Wrocław, Poland

Oxicams (e.g. piroxicam, meloxicam) are widely used nonsteroidal anti-inflammatory drugs (NSAIDs). A large body of evidence from epidemiological and preclinical studies has shown that NSAIDs have a chemopreventive effect on different types of cancer, especially in colorectal cancer. Moreover, mounting evidence from preclinical and clinical studies suggests that persistent inflammation functions as a driving force in the journey to cancer. What is more, inflammation induces reactive oxygen and nitrogen species, which cause damage to important cellular components (e.g., DNA, proteins and lipids), which can directly or indirectly contribute to malignant cell transformation. In this study, we discuss the synthesis and the resultant newly synthesized oxicam derivatives which are potentially chemopreventive, and at the same time antioxidant. Compound $\mathbf{9 c}$, with the highest therapeutic index in the LoVo cancer cell line, was found to be the most efficient in ROS scavenging activity under conditions of oxidative stress.

Key words: synthesis, chemoprevention, antioxidant, COX, NSAIDs, oxicams

Received: 31 January, 2018; revised: 15 May, 2018; accepted:

15 May, 2018; available on-line: 15 June, 2018

e-mail: berenika.szczesniak-siega@umed.wroc.pl (BSzS); jadwiga. maniewska@umed.wroc.pl (JM)

*This subject was presented at the 5th European Joint Theoretical/ Experimental Meeting on Membranes (EJTEMM); December 6-8, 2017 Kraków, Poland

Abbreviations: NSAIDs non-steroidal anti-inflammatory drugs; COX cyclooxygenase; ROS reactive oxygen species; DMF dimethylformamide; TEA triethylamine; CNS central nervous system

\section{INTRODUCTION}

The term chemoprevention was introduced forty years ago by Michael B. Sporn, and defined as the use of natural, synthetic or biological agents to reverse, suppress or prevent either the initial phases of carcinogenesis or the progression of premalignant cells to an invasive disease (Sporn, 1976). It is very important to note that chemoprevention is not aimed at taking over the role of surgery and chemotherapy itself. It is rather a kind of adjuvant therapy involving perturbation of a variety of steps in tumor initiation, promotion and progression. Although a small number of published randomized trials have shown that some chemopreventive therapies may indeed be effective against cancer, there is still need to develop guidelines for management of patients with higher risk of cancer or early treatment with adjuvant chemoprevention therapy (Ulrich et al., 2006; Rostom et al., 2007; Harris et al., 2008; Rothwell et al., 2010 \& 2011; Gravitz, 2011; Boghossian et al., 2012; Cook et al., 2013; Mansouri et al., 2013; Sahin et al., 2014).

Non-steroidal anti-inflammatory drugs (NSAIDs) have been one of the most promising agents in chemoprevention, especially for colorectal cancer (Piazuelo et al., 2015). They are widely used medications with a wellknown molecular target. Their activity involves inhibition of the prostaglandin $\mathrm{H}_{2}$ synthase (PGHS), also commonly called cyclooxygenase (COX). There are three known isoforms of the COX enzymes, the two most important are: COX-1 - the constitutive form, and COX-2 - the inducible form of the enzyme (Vane et al., 1998). COX-3 is a poorly understood isoform of COX occurring mainly in the CNS (Dhingra et al., 2014).

In the last two decades a lot of research results showing the connection between the overexpression of COX2 and occurrence of many human malignancies, e.g. colorectal, breast, pancreatic and lung cancer, were published (Gupta et al., 2001; Ghosh et al., 2010). The data revealed that COX-2 plays a role in different stages of cancer progression, as well as metastasis formation (Lee et al., 2007). Targeting COX-2 is one of the recent therapeutic methods for the treatment of many types of cancer (Dannenberg et al., 2001; Al-Fayez et al., 2006).

NSAIDs are mainly used to treat pain, arthritis and fever. Low-dose of aspirin therapy ( $75 \mathrm{mg}$ per day) has also proven to be effective in reducing the risk of stroke and heart attack, but recently inhibition of COX-1 causing inhibition of platelet activation, facilitation of immunosurveillance and prevention of haematogenous spread of malignancy has been suggested as another putative mechanism of cancer prevention (Thun et al., 2012). Nevertheless, the main NSAID anticancer mechanism is thought to be the decrease of synthesis of prostaglandin $\mathrm{E}_{2}$ via COX-2 inhibition which causes a decrease in tumor cell proliferation and angiogenesis, and increase in apoptosis. Although many of the NSAID anticancer mechanisms are defined as COX dependent, several signal transduction pathways (including for example nuclear factor-kappa B) have been confirmed as NSAIDs' COX independent way of acting (Greenspan et al., 2011; Liao et al., 2012). The correlation between the COX enzyme expression and cancer, together with prognosis factors and putative chemopreventive agents, have been widely studied and reviewed in the literature (Martin et al., 2013; Park et al., 2014).

We designed and synthesized new compounds with potential chemopreventive activity. The lead structure for the synthesis was oxicam scaffold. Oxicams (e.g. piroxicam, meloxicam) belong to the NSAID group. As 
oxicam analogues, our new compounds were believed to possess an analgesic and anti-inflammatory activity via COX inhibition. Their cytotoxicity, as well as antioxidant properties, were also examined because an additional benefit expected in chemoprevention of cancer is ROS scavenging activity (Romero-Canelón et al., 2015).

\section{MATERIALS AND METHODS}

\section{Chemicals}

Sulforhodamine (SRB), Trizma-base and trichloroacetic acid (TCA) were purchased from Sigma-Aldrich (St. Louis, MO, USA). Fetal bovine serum (FBS), $2 \mathrm{mM}$ L-glutamine solution, antibiotic solutions: penicillin (100 $\mathrm{U} / \mathrm{mL})$ and streptomycin $(0.1 \mathrm{mg} / \mathrm{mL})$, and trypsin EDTA solution were obtained from Lonza (Verviers, Belgium). Cell culture plastic flasks $\left(75 \mathrm{~cm}^{2}\right)$, as well as 96-wells culture plastic plates, were purchased from Lonza (Verviers, Belgium). Phosphate buffered saline (PBS) and $0.4 \%$ trypan blue solution were obtained from POCH (Gliwice, Poland). All other chemicals used in this study were of analytical grade.

\section{Synthesis}

Unless otherwise noted, chemicals and reagents were obtained from commercial suppliers and used without further purification. Dry solvents were obtained according to the standard procedure. All reactions were monitored by thin layer chromatography on silica gel 60 F254-coated TLC plates (Fluka Chemie $\mathrm{GmbH}$ ) and visualized by UV light at $254 \mathrm{~nm}$. Flash column chromatography on silica gel column (230-400 mesh) was used to purify the final product. Melting points were recorded using open capillary tubes and are uncorrected. The proton nuclear magnetic resonance $\left({ }^{1} \mathrm{H} \mathrm{NMR}\right)$ spectra were measured on a Bruker $300 \mathrm{MHz}$ NMR spectrometer using $\mathrm{CDCl}_{3}$ or DMSO- $d_{6}$ as solvents and tetramethylsilane (TMS) as an internal reference. Chemical shifts are reported in parts per million (ppm). Signal multiplicities were characterized as: s (singlet), brs (broad singlet), d (doublet), $\mathrm{t}$ (triplet), $\mathrm{q}$ (quartet), quin (quintet) and $\mathrm{m}$ (multiplet). Infrared spectra were recorded on a PerkinElmer Spectrum Two UATR FT-IR spectrometer, and frequencies are reported in $\mathrm{cm}^{-1}$. Samples were applied as solids. Elemental analyses for carbon, hydrogen and nitrogen were carried out on a Carlo Erba NA 1500 analyzer and were within $\pm 0.4 \%$ of the theoretical value.

General procedure for the preparation of 2-[3-(4-arylpiperazinyl)propyl]-4-bydroxy-3-(4-substituted-benzoyl)-2H-1,2benzothiazine 1,1-dioxides $8 a-i$ and 2-[2-(4-ary/piperazinyl)2-oxoethyl]-4-bydroxy-3-(4-substituted-benzoyl)-2H-1,2-benzothiazine 1,1-dioxides 9a-g (Scheme 1).

Synthesis and experimental data for the 1,1-dioxo2-[2-oxo-2-(p-substituted-phenyl)etbyl]-1,2-benzotbiazol-3-one 3a-d compounds were previously reported (Krzyżak et al., 2014; Szczęśniak-Sięga et al., 2014; Yoshimura et al., 2015).

Synthesis of 1,1-dioxo-3-(p-substituted-benzoyl)-4-bydroxy2H-1,2-benzothiazines 4a-d

Synthesis and experimental data of compounds $4 a, 4 b$ and 4d were previously reported (Krzyżak et al., 2014; Szczęśniak-Sięga et al., 2014).

Synthesis of 1,1-dioxo-3-(p-methylbenzoyl)-4-bydroxy-2H1,2-benzothiazine $4 \mathbf{c}$

Three millimoles of $3 \mathrm{c}$ were dissolved in $7.5 \mathrm{ml}$ sodium ethoxide $(0.23 \mathrm{~g}$ of $\mathrm{Na}$ in $10 \mathrm{ml}$ of anhydrous eth- anol) at $40^{\circ} \mathrm{C}$ and stirred with heating to $55-60^{\circ} \mathrm{C}$ for 15 min. Color changes from white to deep red were observed. After dissolving all of the substance, the mixture was rapidly cooled to $25^{\circ} \mathrm{C}$ and $7.5 \mathrm{ml}$ of $\mathrm{HCl}(9 \%)$ were added. The color changed from deep red to deep yellow and the product precipitated. The solid was filtered off, dried, and purified by crystallization from $\mathrm{EtOH}$ to give $4 \mathrm{c}$ with $85 \%$ yield.

1,1-dioxo-3-(p-methylbenzoyl)-4-bydroxy-2H-1,2-benzothiazine 4c $85 \%$ yield, mp $232-233^{\circ} \mathrm{C}$; ${ }^{1} \mathrm{H}$ NMR $(300 \mathrm{MHz}$, $\left.\mathrm{CDCl}_{3}\right) \delta(\mathrm{ppm}): 2.47$ (s, 3H, $\left.\mathrm{CH}_{3}\right), 5.83(\mathrm{~s}, 1 \mathrm{H}, \mathrm{NH})$, 7.28-8.27 (m, 8H, ArH), 15.90 (s, $1 \mathrm{H}, \mathrm{OH}_{\text {enolic }}$. FT-IR $\left(\mathrm{cm}^{-1}\right): 3242(\mathrm{NH}), 1589(\mathrm{C}=\mathrm{O}), 1369,1177$ (SO $)$. Anal. Calcd for $\mathrm{C}_{16} \mathrm{H}_{13} \mathrm{NO}_{4} \mathrm{~S}$ (315.34): C, 60.94; H, 4.16; N, 4.44; Found: C, 60.88; H, 4.19; N, 4.36.

Synthesis and experimental data for the 1-(3-chloropropyl)-4-ary/piperazine 5a-d compounds were previously reported (Lopez et al., 2010; Krzyżak et al., 2014; Maniewska et al., 2014; Paudel et al., 2016).

Synthesis and experimental data for the 1-(2-chloro1-oxoethyl)-4-arylpiperazine 6a-c compounds were previously reported (Szczęśniak-Sięga et al., 2014; Muszalska et al., 2015).

Synthesis and experimental data for the 2-(2-chloro-1oxoethyl)-1,3,4,9-tetrabydro- $\beta$-carboline 7 compound was previously reported (Zhou et al., 2016).

Synthesis of 2-[3-(4-ary/piperazinyl)propyl]-4-bydroxy-3-(4substituted-benzoyl)-2H-1,2-benzothiazine 1,1-dioxides $8 \mathrm{a}-\mathbf{i}$

To the stirred mixture of $5 \mathrm{mmol}$ of corresponding 1,2-benzothiazines 4 a-d in $20 \mathrm{ml}$ of anhydrous EtOH was added to $5 \mathrm{ml}$ of EtONa $(0.115 \mathrm{~g}$ of $\mathrm{Na}$ in $5 \mathrm{ml}$ of anhydrous ethanol). Then, $5 \mathrm{mmol}$ of corresponding 1-(3-chloropropyl)-4-arylpiperazine $\mathbf{5 a - d}$ were added and refluxed with stirring for $10 \mathrm{~h}$. When the reaction ended, which was monitored on TLC plates, ethanol was distilled off, the residue was treated with $50 \mathrm{ml}$ of $\mathrm{CHCl}_{3}$ and the insoluble materials were filtered off. The filtrate was then evaporated and the residue was purified by crystallization from EtOH to give desirable products $\mathbf{8 a -}$ i. Compounds $\mathbf{8 a}, \mathbf{8 d}$ and $\mathbf{8 h}$ were previously described (Krzyżak et al., 2014).

3-benzoyl-4-bydroxy-2-\{3-[4-(2-pyrimidyl)-1-piperazinyl]propyl\}-2H-1,2-benzothiazine 1,1-dioxide 8b $41 \%$ yield, $\mathrm{mp}$ $173-176^{\circ} \mathrm{C} ;{ }^{1} \mathrm{H}$ NMR $\left(300 \mathrm{MHz}, \mathrm{CDCl}_{3}\right) \delta$ (ppm): 1.20 (brs, 2H, $\mathrm{CH}_{2} \mathrm{CH}_{2} \mathrm{CH}_{2}$ ), 1.93 (s, 2H, $\mathrm{CH}_{2} \mathrm{CH}_{2} \mathrm{CH}_{2^{-}}$ $\left.\mathrm{N}_{\text {tiperazine }}\right), 2.11$ (s, 4H, $\left.\mathrm{H}_{\text {piperazine }}\right), 3.17$ (brs, $2 \mathrm{H}$, $\left.\mathrm{CH}_{2} \mathrm{CH}_{2} \mathrm{CH}_{2}\right), 3.64-3.71$ (brs, $4 \mathrm{H}, \mathrm{H}_{\text {piperazine }}$ ), 6.44-6.47 [t, $J=6 \mathrm{~Hz}, 1 \mathrm{H}, \mathrm{CH}(5)_{\text {primidine }}$, 7.48-8.21 (m, 9H, ArH), 8.268.27 [d, J=6 Hz, 2H, CH(4 and 6) prrimidine, 15.75 (s, 1H, $\left.\mathrm{OH}_{\text {enolic }}\right)$. FT-IR $\left(\mathrm{cm}^{-1}\right): 1618(\mathrm{C}=\mathrm{O}), 1346,1178\left(\mathrm{SO}_{2}\right)$. Anal. Calcd for $\mathrm{C}_{26} \mathrm{H}_{27} \mathrm{~N}_{5} \mathrm{O}_{4} \mathrm{~S}$ (505.59): C, 61.77; H, 5.38; N, 13.85; Found: C, 61.69; H, 5.18; N, 13.78.

3-benzoyl-2-\{3-[4-(2-fluorophenyl)-1-piperazinyl]propyl\}-4-bydroxy-2H-1,2-benrothiarine 1,1-dioxide 8c 44\% yield, $\mathrm{mp}$ 147-149 ${ }^{\circ} \mathrm{C}$; ${ }^{1} \mathrm{H}$ NMR (300 $\left.\mathrm{MHz}_{2} \mathrm{CDCl}_{3}\right) \quad \delta$ (ppm): 1.24 (brs, 2H, $\mathrm{CH}_{2} \mathrm{CH}_{2} \mathrm{CH}_{2}$ ), 1.96 (brs, 2H, $\mathrm{CH}_{2} \mathrm{CH}_{2}^{-}$ $\mathrm{CH}_{2} \mathrm{~N}_{\text {piteravine }}$ ), 2.26 (brs, $\left.4 \mathrm{H}, \mathrm{H}_{\text {piperazine }}\right), 2.94-3.60$ [m, $6 \mathrm{H}$, $\left.\mathrm{CH}_{2} \mathrm{~N}\left(\mathrm{CH}_{2}\right)_{2}\right], 6.86-8.21$ (m, $\left.13 \mathrm{H}, \operatorname{ArH}\right), 15.60$ (s, 1H, $\left.\mathrm{OH}_{\text {enolic }}\right)$. FT-IR $\left(\mathrm{cm}^{-1}\right): 1615(\mathrm{C}=\mathrm{O}), 1329,1177\left(\mathrm{SO}_{2}\right)$. Anal. Calcd for $\mathrm{C}_{28} \mathrm{H}_{28} \mathrm{FN}_{3} \mathrm{O}_{4} \mathrm{~S}$ (521.60): C, 64.47; H, 5.41; N, 8.06; Found: C, 64.67; H, 5.35; N, 8.05.

4-hydroxy-3-(4-methoxybenzoyl)-2-\{3-[4-(3-trifluoromethylphenyl)-1-piperazinyl]propyl\}-2H-1,2-benzothiazine 1,1-dioxide 8e $46 \%$ yield, $\mathrm{mp} 121-123^{\circ} \mathrm{C}$; ${ }^{1} \mathrm{H}$ NMR $(300 \mathrm{MHz}$, $\left.\mathrm{CDCl}_{3}\right) \quad \delta$ (ppm): 1.24 (brs, $\left.2 \mathrm{H}, \mathrm{CH}_{2} \mathrm{CH}_{2} \mathrm{CH}_{2}\right), 2.02$ (brs, $\left.2 \mathrm{H}, \mathrm{CH}_{2} \mathrm{CH}_{2} \mathrm{CH}_{2} \mathrm{~N}_{\text {piperazine }}\right), 2.28$ (brs, $4 \mathrm{H}, \mathrm{H}_{\text {piperazine }}$ ), 3.10-3.40 [m, 6H, CH $\left.\mathrm{CH}\left(\mathrm{CH}_{2}\right)_{2}\right], 3.90\left(\mathrm{~s}, 3 \mathrm{H}, \mathrm{OCH}_{3}\right)$, 6.99-8.20 (m, 12H, ArH), 15.78 (s, 1H, OH enolic). FTIR $\left(\mathrm{cm}^{-1}\right)$ : $1605(\mathrm{C}=\mathrm{O}), 1350,1170\left(\mathrm{SO}_{2}\right)$. Anal. Calcd 


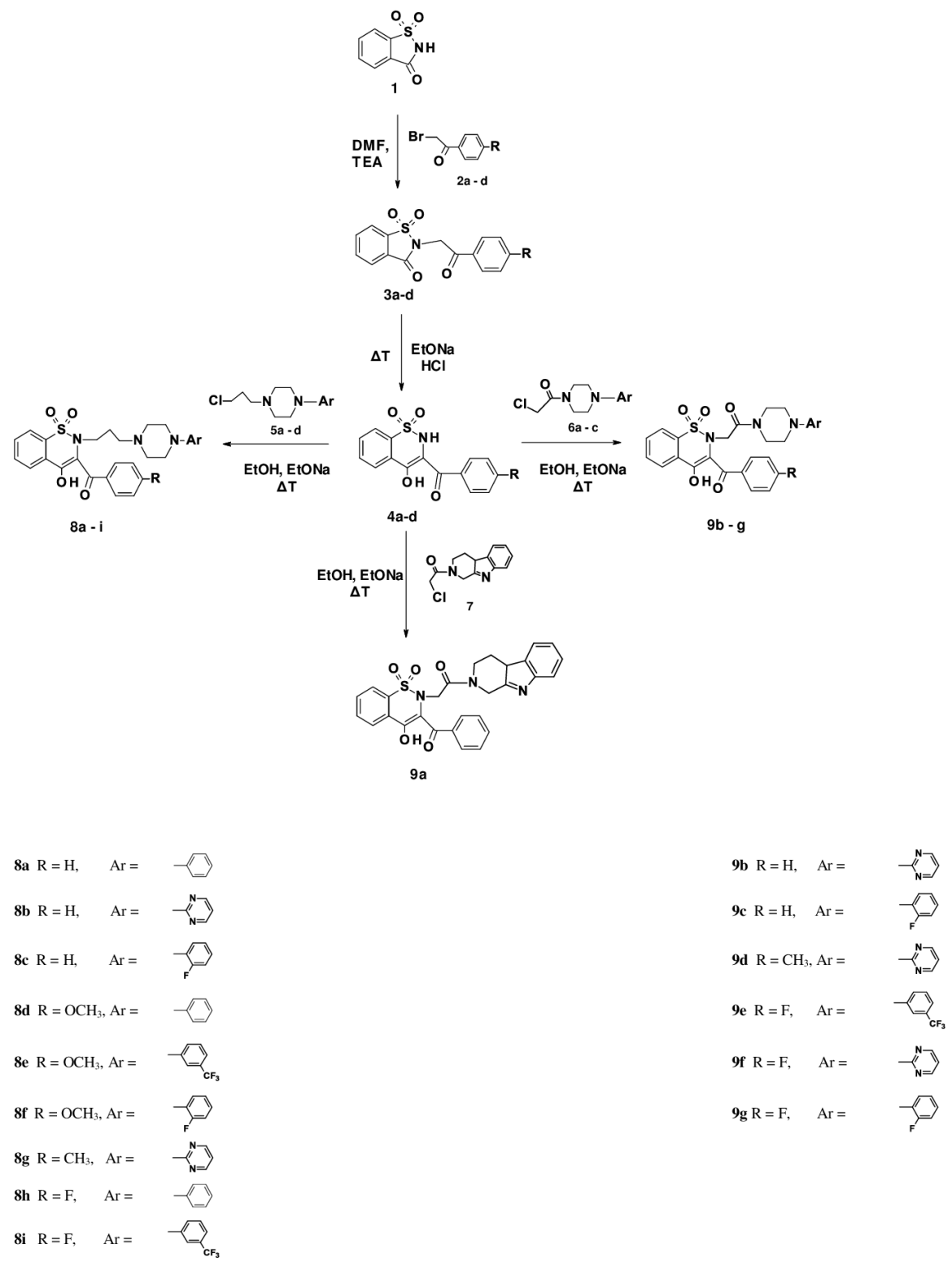

Scheme 1. Synthesis of new oxicam derivative series 8 and series 9.

for $\mathrm{C}_{30} \mathrm{H}_{30} \mathrm{~F}_{3} \mathrm{~N}_{3} \mathrm{O}_{5} \mathrm{~S}$ (601.64): C, 59.89; $\mathrm{H}, 5.03 ; \mathrm{N}, 6.98$; Found: C, 60.25; H, 5.21; N, 6.88.

3-(4-methoxybenzoyl)-4-bydroxy-2-\{3-[4-(2-fluorophenyl)-1-piperazinyl]propyl\}-2H-1,2-benzothiazine 1,1-dioxide 8f $45 \%$ yield, mp $58-60^{\circ} \mathrm{C} ;{ }^{1} \mathrm{H}$ NMR $\left(300 \mathrm{MHz}, \mathrm{CDCl}_{3}\right) \delta$ (ppm): 1.23 (brs, $2 \mathrm{H}, \mathrm{CH}_{2} \mathrm{CH}_{2} \mathrm{CH}_{2}$ ), 2.01 (brs, 2H, $\mathrm{CH}_{2} \mathrm{CH}_{2} \mathrm{CH}_{2}$ $\mathrm{N}_{\text {piperazine }}$ ), 2.29 (brs, 4H, $\left.\mathrm{H}_{\text {tiperazine }}\right), 2.95$ [brs, 6H, $\mathrm{CH}_{2} \mathrm{~N}\left(\mathrm{CH}_{2}\right)_{2}$ ], 3.90 (s, 3H, OCH $\left.{ }_{3}\right), 6.88-8.20(\mathrm{~m}, 12 \mathrm{H}$, $\mathrm{ArH}), 15.71$ (s, 1H, OH enolic $)$. FT-IR $\left(\mathrm{cm}^{-1}\right)$ : $1606(\mathrm{C}=\mathrm{O})$, 1352, $1176\left(\mathrm{SO}_{2}\right)$. Anal. Calcd for $\mathrm{C}_{29} \mathrm{H}_{30} \mathrm{FN}_{3} \mathrm{O}_{5} \mathrm{~S}$ (551.63): C, 63.14; H, 5.48; N, 7.62; Found: C, 62.79; H, $5.86 ; \mathrm{N}, 7.27$.

4-bydroxy-3-(4-methylbenzoyl)-2-\{3-[4-(2-pyrimidyl)-1-piperazinyl]propyl\}-2H-1,2-benzothiazine 1,1-dioxide $\mathbf{8 g} \quad 19 \%$ yield, mp $135-138^{\circ} \mathrm{C}$; ${ }^{1} \mathrm{H}$ NMR $\left(300 \mathrm{MHz}, \mathrm{CDCl}_{3}\right)$ $\delta$ (ppm): 1.26 (brs, 2H, $\left.\mathrm{CH}_{2} \mathrm{CH}_{2} \mathrm{CH}_{2}\right), \quad 1.95-2.12$ $\left[\mathrm{m}, 6 \mathrm{H}, \mathrm{CH}_{2} \mathrm{~N}\left(\mathrm{CH}_{2}\right)_{2}\right], 2.44$ (s, 3H, $\left.\mathrm{CH}_{3}\right), 3.20$ (brs, $2 \mathrm{H}$, $\mathrm{CH}_{2} \mathrm{CH}_{2} \mathrm{CH}_{2}$ ), 3.66 (brs, 4H, H $\left.\mathrm{CH}(5)_{\text {pyrimidine }}\right], 7.30-8.21$ (m, 8H, ArH), 8.27-8.29 [d, $J=6$

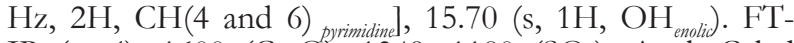
IR $\left(\mathrm{cm}^{-1}\right)$ : $1600(\mathrm{C}=\mathrm{O}), 1349,1180\left(\mathrm{SO}_{2}\right)$. Anal. Calcd for $\mathrm{C}_{27} \mathrm{H}_{29} \mathrm{~N}_{5} \mathrm{O}_{4} \mathrm{~S}$ (519.62): C, 62.41; $\mathrm{H}, 5.63 ; \mathrm{N}, 13.48$; Found: C, 62.11; H, 5.80; N, 13.67.

3-(4-fluorobenzoyl)-4-bydroxy-2-\{3-[4-(3-trifluoromethylphenyl)-1-piperazinyl]propyl\}-2H-1,2-benzothiazine 1,1-dioxide $8 \mathrm{i} 48 \%$ yield, mp $140-143^{\circ} \mathrm{C} ;{ }^{1} \mathrm{H}$ NMR $(300$ $\mathrm{MHz}, \mathrm{CDCl}_{3}$ ) $\delta$ (ppm): 1.29 (brs, $2 \mathrm{H}, \mathrm{CH}_{2} \mathrm{CH}_{2} \mathrm{CH}_{2}$ ), 2.01(brs, 2H, $\mathrm{CH}_{2} \mathrm{CH}_{2} \mathrm{CH}_{2} \mathrm{~N}_{\text {piperazine }}$ ), 2.29 (brs, 4H, $\left.\mathrm{H}_{\text {tiperazine }}\right), 3.10$ [brs, 6H, $\left.\mathrm{CH}_{2} \mathrm{~N}\left(\mathrm{CH}_{2}\right)_{2}\right], 6.98-8.22$ (m, $12 \mathrm{H}, \mathrm{ArH}), 15.51$ (s, 1H, OH $\left.{ }_{\text {enolic }}\right)$ FT-IR $\left(\mathrm{cm}^{-1}\right): 1605$ $(\mathrm{C}=\mathrm{O}), 1355,1175\left(\mathrm{SO}_{2}\right)$. Anal. Calcd for $\mathrm{C}_{29} \mathrm{H}_{27} \mathrm{~F}_{4} \mathrm{~N}_{3} \mathrm{O}_{4} \mathrm{~S}$ (589.60): C, 59.08; H, 4.62; N, 7.13; Found: C, 59.40; H, $4.82 ; \mathrm{N}, 7.02$.

Synthesis of 2-[2-(4-ary/piperazinyl)-2-oxoethyl]-4-bydroxy3-(4-substituted-benzoyl)-2H-1,2-ben rothiazine 1,1-dioxides 9a-g $5 \mathrm{mmol}$ of corresponding 1,2-benzothiazine $4 \mathrm{a}$-d were dissolved in $20 \mathrm{ml}$ of anhydrous EtOH with addition of $5 \mathrm{ml}$ of EtONa $(0.115 \mathrm{~g}$ of $\mathrm{Na}$ in $5 \mathrm{ml}$ of anhydrous 
ethanol). Then, $5 \mathrm{mmol}$ of corresponding 1-(2-chloro-1-oxoethyl)-4-arylpiperazine $\mathbf{6 a - c}$ or 2-(2-chloro-1oxoethyl)-1,3,4,9-tetrahydro- $\beta$-carboline 7 were added and refluxed with stirring for about $10 \mathrm{~h}$. When the reaction ended, which was monitored on TLC plates, ethanol was distilled off, the residue was treated with $50 \mathrm{ml}$ of $\mathrm{CHCl}_{3}$ and insoluble materials were filtered off. The filtrate was then evaporated and the residue was purified by crystallization from ethanol to give desirable products $\mathbf{9 a - g}$. Compounds $9 \mathrm{f}$ and $\mathbf{9 g}$ were previously described (Szczęśniak-Sięga et al., 2014).

3-benzoyl-4-bydroxy-2-[2-(1,3,4,9-tetrabydro- $\beta$-carbolin-2-yl)2-oxoethyl]-2H-1,2-benzothiarine 1,1-dioxide 9a 30\% yield, mp 215-217 ${ }^{\circ} \mathrm{C} ;{ }^{1} \mathrm{H}$ NMR (300 MHz, DMSO- $\left.\mathrm{d}_{6}\right) \delta$ (ppm): $3.33\left[\mathrm{~m}, 4 \mathrm{H}, \mathrm{CH}_{2}(3 \text { and 4) })_{\text {carboline }}\right], 4.16-4.29$ [m, $4 \mathrm{H}, \mathrm{CH}_{2} \mathrm{CO}$ and $\mathrm{CH}_{2}(1)_{\text {carboline }}$, 6.91-8.15 (m, 13H, $\left.\mathrm{ArH}\right)$, 10.69-10.72 (m, 1H, NH), 15.04 (s, 1H, OH enolic $)$. FT-IR $\left(\mathrm{cm}^{-1}\right): 3324(\mathrm{NH}), 1642,1620(\mathrm{C}=\mathrm{O}), 1347,1180\left(\mathrm{SO}_{2}\right)$. Anal. Calcd for $\mathrm{C}_{28} \mathrm{H}_{23} \mathrm{~N}_{3} \mathrm{O}_{5} \mathrm{~S}$ (513.56): C, 65.48; H, 4.51; N, 8.18; Found: C, 65.25; H, 4.44; N, 8.05.

3-benzoyl-4-bydroxy-2-\{2-[4-(2-pyrimidyl)-1-piperazinyl]-2oxoetbyl $\}$-2H-1,2-benzothiazine 1,1-dioxide 9 b $40 \%$ yield,

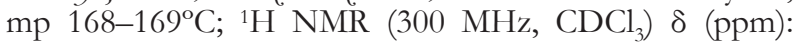
$3.13-4.22\left(\mathrm{~m}, 10 \mathrm{H}, \mathrm{CH}_{2} \mathrm{CO}\right.$ and $\left.8 \mathrm{H}_{\text {piperazine }}\right), 6.50-8.29$ $(\mathrm{m}, 12 \mathrm{H}, \mathrm{ArH}), 15.60\left(\mathrm{~s}, 1 \mathrm{H}, \mathrm{OH}_{\text {enolic }}\right)$. FT-IR $\left(\mathrm{cm}^{-1}\right)$ : 1670, $1590(\mathrm{C}=\mathrm{O}), 1340,1175\left(\mathrm{SO}_{2}\right) ;$; Anal. Calcd for $\mathrm{C}_{25} \mathrm{H}_{23} \mathrm{~N}_{5} \mathrm{O}_{5} \mathrm{~S}$ (505.54): C, 59.39; H, 4.59; N, 13.85; Found: C, 59.21; H, 4.45; N, 13.76 .

3-benzoyl-4-bydroxy-2-\{2-[4-(2-fluorophenyl)-1-piperazinyl]2-oxoetbyl\}-2H-1,2-benzothiazine 1,1-dioxide 9c 56\% yield, mp $140-145^{\circ} \mathrm{C} ;{ }^{1} \mathrm{H}$ NMR $\left(300 \mathrm{MHz}, \mathrm{CDCl}_{3}\right) \delta$ (ppm): 1.66 (brs, 2H, $\left.\mathrm{CH}_{2} \mathrm{CO}\right), 2.86-3.55$ (m, 8H, $\mathrm{H}_{\text {piperazine }}$ ), 6.78-8.27 (m, 13H, ArH), 15.60 (s, 1H, OH enolis $)$. PT-IR $\left(\mathrm{cm}^{-1}\right):$ 1732, $1672(\mathrm{C}=\mathrm{O}), 1344,1180\left(\mathrm{SO}_{2}\right)$; Anal. Calcd for $\mathrm{C}_{27} \mathrm{H}_{24} \mathrm{FN}_{3} \mathrm{O}_{5} \mathrm{~S}$ (521.56): C, 62.18; H, 4.64; N, 8.06; Found: C, 62.30; H, 4.78; N, 7.84.

4-bydroxy-3-(4-methylbenzoyl)-2-\{2-[4-(2-pyrimidyl)-1-piperazinyl]-2-oxoethyl $\}$-2H-1,2-benzothiazine 1,1-dioxide 9d 41\% yield, mp $205-207^{\circ} \mathrm{C}$; ${ }^{1} \mathrm{H}$ NMR $\left(300 \mathrm{MHz}, \mathrm{CDCl}_{3}\right) \delta$ (ppm): 2.43 (s, 3H, $\left.\mathrm{CH}_{3}\right), 3.15-4.21\left(\mathrm{~m}, 10 \mathrm{H}, \mathrm{CH}_{2} \mathrm{CO}\right.$ and $\left.8 \mathrm{H}_{\text {piperazine }}\right), 6.50-8.29(\mathrm{~m}, 11 \mathrm{H}, \mathrm{ArH}), 15.65(\mathrm{~s}, 1 \mathrm{H}$, $\mathrm{OH}_{\text {enolic }}$. F FT-IR $\left(\mathrm{cm}^{-1}\right): 1665,1600(\mathrm{C}=\mathrm{O}), 1340,1180$ $\left(\mathrm{SO}_{2}\right)$; Anal. Calcd for $\mathrm{C}_{26} \mathrm{H}_{25} \mathrm{~N}_{5} \mathrm{O}_{5} \mathrm{~S}$ (519.57): C, 60.10; H, 4.85; N, 13.48; Found: C, 60.15; H, 4.86; N, 13.41 .

3-(4-fluorobenzoyl)-4-bydroxy-2-\{2-[4-(3-trifluoromethy/phenyl)1-piperazinyl]-2-oxoethyl\}-2H-1,2-benzothiazine 1,1-dioxide $9 \mathrm{e}$ $54 \%$ yield, mp $158-160^{\circ} \mathrm{C} ;{ }^{1} \mathrm{H}$ NMR $\left(300 \mathrm{MHz}^{\circ} \mathrm{CDCl}_{3}\right.$ ) $\delta$ (ppm): $3.05-3.32\left(\mathrm{~m}, 10 \mathrm{H}, \mathrm{CH}_{2} \mathrm{CO}\right.$ and $8 \mathrm{H}$ 6.99-8.27 (m, 12H, ArH) 15.49 (s, 1H, OH $\left.\mathbf{H}_{\text {enolic }}\right)$. FT-IR $\left(\mathrm{cm}^{-1}\right)$ : 1666, $1610(\mathrm{C}=\mathrm{O}), 1345,1180\left(\mathrm{SO}_{2}\right)$; Anal. Calcd for $\mathrm{C}_{28} \mathrm{H}_{23} \mathrm{~F}_{4} \mathrm{~N}_{3} \mathrm{O}_{5} \mathrm{~S}$ (589.56): C, 57.04; H, 3.93; N, 7.13; Found: C, 57.37; H, 3.80; N, 6.95.

\section{Cells}

Normal human dermal fibroblasts (NHDF) from adult donors, were purchased from Lonza (Verviers, Belgium). Normal cell line V79 (fibroblasts from Chinese Hamster lung) and human cancer cell lines: A549 (pulmonary basal cell alveolar adenocarcinoma), LoVo (colon adenocarcinoma) were obtained from the European Collection of Authenticated Cell Cultures (ECACC).

\section{Cell and culture conditions}

Cells were grown in the culture media recommended by the cell line supplier. Before the test, adherent cells were detached with the trypsin EDTA solution, and FBS containing medium was used to neutralize the effects of Trypsin/EDTA solution. Then, the cells were spun down, counted, stained with a $0.4 \%$ solution of trypan blue, and inspected under a microscope for cell viability. Afterwards, cells were placed in 96-well plastic culture plates $\left(2 \times 10^{3}\right.$ cells/well $)$ and incubated at $37^{\circ} \mathrm{C}$ in a $\mathrm{CO}_{2}$-incubator for $24 \mathrm{~h}$. Next, the cells were incubated with different concentrations of all of the tested compounds $(5,10,20,50$ and $100 \mu \mathrm{M})$. The cultures were incubated for $48 \mathrm{~h}$ in the $\mathrm{CO}_{2}$-incubator at $37^{\circ} \mathrm{C}$, after which the cells were harvested and used for cell proliferation test.

\section{Determination of cell proliferation}

Cell proliferation was estimated with the sulforhodamine B (SRB)-colorimetric assay (Vichai et al., 2006). Briefly, cell cultures were fixed with cold TCA (final concentration $10 \% \mathrm{w} / \mathrm{v}$ ) in cultures of adherent cells for $1 \mathrm{~h}$ at $4^{\circ} \mathrm{C}$, then washed four times with tap water and air-dried at room temperature $\left(20-25^{\circ} \mathrm{C}\right)$. A mildly acidic SRB solution $(0.4 \%$ dye solution in $1 \%$ acetic acid) was added to each well for $30 \mathrm{~min}$ at $25^{\circ} \mathrm{C}$, and then unbound stain was removed by rinsing with an aqueous solution of $1 \%(\mathrm{v} / \mathrm{v})$ acetic acid. Culture plates were then allowed to dry at room temperature. The proteinbound dye was dissolved in $10 \mathrm{mM}$ Tris base solution ( $\mathrm{pH} 10.5)$ for $10 \mathrm{~min}$ on a gyratory shaker. Absorbance of the SRB solution was estimated at $540 \mathrm{~nm}$ in a Victor 2 microplate reader (Perkin-Elmer, MA, USA).

\section{Evaluation of Intracellular ROS Level}

Intracellular ROS levels were determined using non-polar, non-fluorescent 2'7'-dichlorodihydrofluorescein diacetate (DCFH-DA) as a marker of oxidative stress at final concentration of $25 \mu \mathrm{M}$. Following treatment with all of the tested compounds for $4 \mathrm{~h}$, the V79 cell cultures were incubated with a medium $(200 \mu \mathrm{l})$ with non-fluorescence probe DCFH-DA for the last $2 \mathrm{~h}$ of culture in the dark at $37^{\circ} \mathrm{C}$ and $5 \% \mathrm{CO}_{2}$, according to a standard procedure (Eruslanov et al., 2010). Then, the cells were washed twice with PBS and treated with $\mathrm{H}_{2} \mathrm{O}_{2}(100 \mu \mathrm{M})$ for $30 \mathrm{~min}$. DCFH-DA probe penetrates through the membrane by passive diffusion and then it is hydrolyzed enzymatically by intracellular esterases to the polar, non-fluorescent form of 2',7'-dichlorodihydrofluorescin $(\mathrm{DCFH})$. DCFH is immediately oxidized in the presence of reactive oxygen species (ROS) to highly fluorescent 2',7'-dichlorofluorescin (DCF).

Fluorescence of DCF was measured $\left(\lambda_{\mathrm{ex}}=485 \mathrm{~nm}\right.$, $\lambda_{\text {em }}=535 \mathrm{~nm}$ ) in a Victor 2 microspectrophotometer (PerkinElmer, Waltham, MA, USA). The applied concentration of $\mathrm{H}_{2} \mathrm{O}_{2}$ was $100 \mu \mathrm{M}$. Thirty-minute cell incubation with $\mathrm{H}_{2} \mathrm{O}_{2}$ was chosen, as data found in the literature strongly suggest that cells were able to decompose almost all of the $\mathrm{H}_{2} \mathrm{O}_{2}$ added to the culture medium within $30 \mathrm{~min}$ (Loo et al., 2012). The test results are presented as the $\mathrm{E} / \mathrm{E}_{0}$ ratio. The $\mathrm{E} / \mathrm{E}_{0}$ ratio is the comparison of the test sample value (E) to the control value $\left(\mathrm{E}_{0}\right)$. The effect of increased generation of ROS was observed in the $\mathrm{H}_{2} \mathrm{O}_{2}$ induced cells in contrast to the non-oxidized stress cells. $\mathrm{H}_{2} \mathrm{O}_{2}$ is extensively used to induce oxidative stress in vitro. The products of $\mathrm{H}_{2} \mathrm{O}_{2}$, i.e. superoxide and hydroxyl radicals, are major components of ROS.

\section{In vitro cyclooxygenase inhibitory activity}

COX Colorimetric Inhibitor Screening Assay Kit (Cayman Chemical Company, Ann Arbor, MI). This method allows to estimate the peroxidase activity 
of COX by colorimetric monitoring of occurrence of the oxidized form of N,N,N',N'-tetramethyl-p-phenylenediamine (TMPD) at $590 \mathrm{~nm}$. TMPD is a substrate for most enzymes with peroxidase activity, and high throughput microplate assays using TMPD allow the rapid screening of a wide range of therapeutics that inhibit COX activity in vitro. The test is based on oxidation of TMPD during reduction of $\mathrm{PGG}_{2}$ (prostaglandin $G_{2}$ ) to $\mathrm{PGH}_{2}$, which is reflected by a change in color, measured spectrophotometrically (Victor 2 microspectrophotometer, PerkinElmer Waltham, MA, USA). The assay uses Tris- $\mathrm{HCl}$ buffer $(0.1 \mathrm{M}$ assay buffer, $\mathrm{pH}$ 8.0), a solution of heme in dimethylsulfoxide (DMSO), enzymes (COX-1, COX-2), arachidonic acid $(100 \mu \mathrm{M}), \mathrm{KOH}(0.1 \mathrm{M})$ and a solution of TMPD. The assay mixture contains: $150 \mu \mathrm{L}$ of assay buffer, 10 $\mu \mathrm{L}$ of heme, and $10 \mu \mathrm{L}$ of COX-1 or COX-2. To determine $100 \%$ enzyme activity (each COX sample was assayed in triplicate) $10 \mu \mathrm{L}$ of the substances used as solvents (methanol, ethanol, DMSO) were added to the wells. $10 \mu \mathrm{L}$ of the tested inhibitors at appropriate concentrations were added to the other wells. $20 \mu \mathrm{L}$ of TMPD were added to all of the wells. The reaction was initiated by the addition of arachidonic acid. The effect of the inhibitors tested on COX-1 and COX-2 enzyme activity was measured by assaying the rate of TMPD oxidation within $2 \mathrm{~min}$ in a spectrophotometer at 590 $\mathrm{nm}$. We determined the activity factor at $2 \mathrm{~min}$ of incubation with the tested compounds in comparison to the initial activity of the enzyme. This enabled the calculation of $\mathrm{IC}_{50}$ values (concentrations at which 50\% inhibition of the enzyme's activity occurred).

\section{Statistical analysis}

Statistical significance of the results was calculated with the paired t-test and with Two-way analysis of variance ANOVA, following routine statistical methods.

\section{RESULTS AND DISCUSSION}

\section{Chemistry}

The synthesis of the novel oxicam derivatives was performed according to the reaction pathways illustrated in Scheme 1. Compounds $3 \mathbf{a}-\mathbf{d}$ and $\mathbf{4 a - d}$ were synthesized according to the described procedures (Krzyżak et al., 2014; Szczęśniak-Sięga et al., 2014; Yoshimura et al., 2015). Briefly, commercially available saccharine 1 was condensed with appropriate bromoacetophenones 2a-d in the presence of dimethylformamide (DMF) and triethylamine (TEA) at room temperature. Then, the obtained 2a-d compounds were converted by Gabriel-Colman rearrangement into compounds $3 \mathrm{a}-\mathrm{d}$. Compounds $\mathbf{5 a - d}$ and $\mathbf{6 a - c}$ were also synthesized according to the previously described procedure (Lopez et al., 2010; Krzyżak et al., 2014; Maniewska et al., 2014; Muszalska et al., 2015; Paudel et al., 2016), by alkylation or acylation of the corresponding arylpiperazines. Whereas compound 7 was obtained in a reaction of chloroacetyl chloride with 2,3,4,9-tetrahydro-1H- $\beta$-carboline (Zhou et al., 2016).

The final compounds were obtained by 4 a-d alkylation with $\mathbf{5 a - d}, \mathbf{6 a - c}$ or 7 in the presence of sodium ethoxide (EtONa) with medium yields. All new compounds were divided into two series - series 8 with a propylene linker between thiazine and piperazine nitrogens, and series 9 with an 2-oxoethylene linker in the same position.
Table 1. IC $\mathrm{C}_{50}$ values (SD) calculated for COX-1 and COX-2 activities at 2 min of incubation with the tested compounds (mean S.D.; $n=3$ )

\begin{tabular}{|c|c|c|c|}
\hline \multirow{2}{*}{ Compound } & \multicolumn{2}{|c|}{$\mathrm{IC}_{50}[\mu \mathrm{M}],(\mathrm{SD})$} & \multirow{2}{*}{$\begin{array}{l}\text { Ratio: } \\
\text { COX-2/COX-1 }\end{array}$} \\
\hline & COX-1 & COX-2 & \\
\hline $8 a$ & NA & NA & \\
\hline $8 b$ & $69.3(11.4)^{*}$ & NA & \\
\hline $8 c$ & NA & NA & \\
\hline $8 d$ & NA & NA & \\
\hline $8 e$ & NA & NA & \\
\hline $8 f$ & NA & NA & \\
\hline $8 g$ & NA & NA & \\
\hline $8 \mathrm{~h}$ & NA & NA & \\
\hline $8 \mathrm{i}$ & NA & NA & \\
\hline $9 a$ & NA & NA & \\
\hline $9 b$ & $63.0(3.9)^{* \Delta}$ & $924.2(268.8)^{* \Delta}$ & 14.7 \\
\hline $9 c$ & $157.1(35.3)^{\Delta}$ & NA & \\
\hline $9 d$ & NA & NA & \\
\hline $9 e$ & NA & NA & \\
\hline $9 f$ & NA & NA & \\
\hline $9 g$ & NA & NA & \\
\hline meloxicam & $85.8(12.5)$ & $71.5(5.1)$ & 0.8 \\
\hline piroxicam & $170.5(15.7)$ & 127.6 (11.9) & 0.7 \\
\hline
\end{tabular}

The $t$-test paired to evaluate the inhibition of COX-1 and COX-2 activity compared to the piroxicam control compound $\left({ }^{*} p<0.05\right)$ and the meloxicam control compound $(\Delta p<0.05)$.

\section{In vitro cyclooxygenase inhibitory activity}

The impact of piroxicam and meloxicam (the standard inhibitors of cyclooxygenases from the group of oxicams) on COX-1 and COX-2 activities at 2 min of incubation, as recommended for the test kit carried out in comparison to 16 studied compounds, was tested. The $\mathrm{IC}_{50}$ values (i.e. the concentration of the tested compounds in $\mu \mathrm{M}$ which can exert $50 \%$ inhibition of the enzyme's activity) were calculated separately for COX-1 and COX-2 activity estimations at 2 min of incubation with the tested compounds. Selectivity of the compounds for COX-1 or COX-2 was assessed by calculation of the $\mathrm{IC}_{50}$ ratios. The $\mathrm{IC}_{50}$ values were not calculated for those tested compounds which exerted very low or no inhibitory activity at $2 \mathrm{~min}$ of incubation. Results of the calculations are given in Table 1 .

Compounds $8 \mathbf{a}, \mathbf{8 c - 8 i}, 9 \mathbf{a}$ and $9 \mathbf{d}-\mathbf{9} \mathbf{g}$ showed no in vitro COX inhibitory activity when tested with the method applied. Whereas, compounds $\mathbf{8 b}, \mathbf{9 b}$ and $\mathbf{9 c}$ exerted significant COX-1 selectivity at lower doses than piroxicam. Compounds $\mathbf{8 b}$ and $\mathbf{9 b}$, which possess a pyrimidine ring in their structure and an unsubstituted benzene ring $(\mathrm{R}=\mathrm{H})$ at the thiazine 3 position, have even shown a greater COX-1 inhibition than the meloxicam standard $\left(\mathrm{IC}_{50}=69.3\right.$ and $63.0 \mathrm{vs} \mathrm{IC}_{50}=85.8$, respectively). Compound $\mathbf{9 c}$ also possesses an unsubstituted benzene 
Table 2. ROS scavenging activity of the tested compounds (mean S.D.; $\mathbf{n} 3$ ); the results were compared to the relative control samples (without tested compounds; E0) and expressed as E/EO ratios

\begin{tabular}{|c|c|c|c|c|c|c|}
\hline \multirow[b]{2}{*}{ compound } & \multicolumn{3}{|c|}{ without $\mathrm{H}_{2} \mathrm{O}_{2}$} & \multicolumn{3}{|c|}{ with $\mathrm{H}_{2} \mathrm{O}_{2}$} \\
\hline & mean $\mathrm{E} / \mathrm{E}_{0}$ & S.D. & $p$ & mean $\mathrm{E} / \mathrm{E}_{0}$ & S.D. & $p$ \\
\hline $8 a$ & 0.95 & 0.02 & NS & 1.05 & 0.01 & $0.02^{*}$ \\
\hline $8 b$ & 0.99 & 0.04 & NS & 1.10 & 0.25 & NS \\
\hline $8 c$ & 0.88 & 0.03 & NS & 0.84 & 0.01 & $0.001^{*}$ \\
\hline $8 d$ & 0.85 & 0.01 & NS & 0.87 & 0.05 & NS \\
\hline $8 \mathrm{e}$ & 0.92 & 0.07 & NS & 0.90 & 0.03 & $0.04^{*}$ \\
\hline $8 f$ & 0.89 & 0.01 & $0.001^{*}$ & 0.74 & 0.14 & NS \\
\hline $8 g$ & 1.05 & 0.04 & NS & 1.04 & 0.17 & NS \\
\hline $8 \mathrm{~h}$ & 0.94 & 0.06 & NS & 0.87 & 0.14 & NS \\
\hline $8 \mathrm{i}$ & 0.81 & 0.06 & $0.04^{*}$ & 0.86 & 0.15 & NS \\
\hline $9 a$ & 0.89 & 0.05 & NS & 1.05 & 0.01 & $0.03^{*}$ \\
\hline $9 b$ & 1.03 & 0.04 & NS & 1.11 & 0.00 & NS \\
\hline $9 c$ & 0.92 & 0.06 & NS & 0.88 & 0.02 & $0.01^{*}$ \\
\hline $9 d$ & 0.95 & 0.17 & NS & 1.15 & 0.22 & NS \\
\hline $9 e$ & 0.84 & 0.03 & $0.01^{*}$ & 0.72 & 0.12 & NS \\
\hline $9 f$ & 1.14 & 0.03 & $0.02^{*}$ & 1.35 & 0.04 & $0.01^{*}$ \\
\hline $9 g$ & 1.00 & 0.04 & NS & 1.14 & 0.18 & NS \\
\hline meloxicam & 0.99 & 0.20 & NS & 1.22 & 0.14 & NS \\
\hline piroxicam & 1.19 & 0.17 & NS & 1.59 & 0.25 & NS \\
\hline ascorbic acid & 0.80 & 0.12 & NS & 0.18 & 0.07 & $0.001^{*}$ \\
\hline trolox & 0.78 & 0.08 & $0.01^{*}$ & 0.15 & 0.05 & $0.001^{*}$ \\
\hline
\end{tabular}

*Statistical significance $(p)$ was assessed with the $t$-test paired $(p<0.05)$

ring $(\mathrm{R}=\mathrm{H})$ at the thiazine 3 position, but instead of the pyrimidine ring it has an o-fluorophenyl substituent and shows less inhibition of COX-1 than meloxicam, but stronger than piroxicam $\left(\mathrm{IC}_{50}=170.5>157.1>85.8\right.$, respectively). Only compound $9 \mathbf{b}$ exhibited COX-2 inhibition as well, but that was at higher dose then the reference drugs - piroxicam and meloxicam $\left(\mathrm{IC}_{50}=924.2>\right.$ $127.6>71.5$, respectively). The structure-activity relationship (SAR) in this group of compounds is rather difficult to determine due to the fact that only 3 out of 16 tested compounds showed COX-1/COX-2 inhibitory activity.

\section{Evaluation of Intracellular ROS Level}

The ROS scavenging activity of 16 new compounds and two oxicams - piroxicam and meloxicam - in the presence and absence of oxidative stress (generated by addition of $\mathrm{H}_{2} \mathrm{O}_{2}$ to cell cultures) is shown in Table 2. Compounds $\mathbf{8 f}, \mathbf{8 i}$ and $\mathbf{9 e}$ showed significant ROS scavenging activity under normal conditions. In contrast, compound 9f caused an increase in the ROS concentration under normal conditions, as well as during oxidative stress (induced by adding $\mathrm{H}_{2} \mathrm{O}_{2}$ ). However, compounds $8 \mathrm{a}, \mathbf{8 c}, \mathbf{8 e}, \mathbf{9 a}$ and $\mathbf{9 c}$ were very efficient at ROS scavenging under oxidative stress, in contrast to oxicams. Moreover, there seems to be no structure-activity relationship between the structure of the new com- pounds and their ROS scavenging activity measured by the method applied. The antioxidant activity of all of the tested compounds was lower than standard ROS scavengers - ascorbic acid and trolox.

\section{Determination of cell proliferation}

Cell proliferation was estimated with the sulforhodamine B (SRB)-colorimetric assay (Vichai et al., 2006). New compounds and two reference drugs (piroxicam and meloxicam) were tested on two normal cell lines (normal human dermal fibroblasts NHDF and fibroblast from Chinese Hamster lung V79) and two human cancer cell lines (colon adenocarcinoma, LoVo, and pulmonary basal cell alveolar adenocarcinoma, A549). The results are shown in Table 3. All compounds from the series 8 did not inhibit the growth of both, normal and cancerous cells. On the other hand, compounds from series 9 displayed a significant activity in inhibiting the growth of cancer cells (both, LoVo and A549, or only one of them), with the exception of compound 9e. Compound 9c showed the highest therapeutic index (the largest difference between concentrations inhibiting 50\% growth of normal and cancerous cells), among the tested compounds. Therefore, the presence of a two-carbon aliphatic linker with a carbonyl group between the thiazine and piperazine nitrogens in series $\mathbf{9}$, instead of a three-car- 
Table 3. IC 50 values (S.D.) calculated for NHDF, V79, LoVo and V79 cell lines at $48 \mathrm{~h}$ of incubation with the tested compounds (mean S.D.; $\mathbf{n}=3$ )

\begin{tabular}{|c|c|c|c|c|}
\hline \multicolumn{5}{|c|}{$\mathrm{IC}_{50}[\mu \mathrm{M}],(\mathrm{S} . \mathrm{D})}$. \\
\hline compound & NHDF & V79 & LoVo & A549 \\
\hline $8 a$ & NA & NA & NA & NA \\
\hline $8 b$ & NA & NA & NA & NA \\
\hline $8 c$ & NA & NA & NA & NA \\
\hline $8 d$ & NA & NA & NA & NA \\
\hline $8 e$ & NA & NA & NA & NA \\
\hline $8 f$ & NA & NA & NA & NA \\
\hline $8 g$ & NA & NA & NA & NA \\
\hline $8 \mathrm{~h}$ & NA & NA & NA & NA \\
\hline $8 \mathrm{i}$ & NA & NA & NA & NA \\
\hline $9 a$ & NA & $199.42(43.0)$ & NA & $411.1(46.8)$ \\
\hline $9 b$ & $131.3(20.4)$ & $128.56(7.9)$ & $126.6(7.9)$ & $163.8(2.8)$ \\
\hline $9 c$ & $433.3(184.5)$ & $247.17(37.5)$ & $243.9(55.7)$ & $347.3(46.1)$ \\
\hline $9 d$ & $259.0(107.8)$ & $207.2(80.2)$ & $504.5(316.0)$ & $542.8(181.2)$ \\
\hline $9 e$ & 474.5 (291.6) & $282.0(169.1)$ & NA & NA \\
\hline $9 f$ & $136.5(17.6)$ & $129.3(34.9)$ & $124.2(7.1)$ & $185.9(9.0)$ \\
\hline $9 g$ & $283.3(123.5)$ & $182.8(80.4)$ & NA & 437.5 (191.0) \\
\hline meloxicam & $205.6(44.2)$ & $231.8(33.5)$ & $124.6(11.2)$ & $148.3(37.9)$ \\
\hline piroxicam & $170.5(23.0)$ & $200.0(32.9)$ & $122.1(9.6)$ & $138.1(27.8)$ \\
\hline
\end{tabular}

bon linker in series $\mathbf{8}$, seems to be crucial for cytotoxic activity of the compounds studied. The cytotoxic activity of the new compounds against the LoVo line seems to be particularly important, as studies in recent years have proved that NSAIDs are very useful in colorectal cancer chemoprevention (Wakeman et al., 2017).

\section{CONCLUSIONS}

The COX inhibiting activity, the ROS scavenging activity, and cytotoxicity of the 16 new oxicam derivatives were examined in order to assess the chemopreventive potential of the compounds studied. We have shown that COX inhibiting activity and cytotoxicity depend on the structure of the individual compounds. From the structure-activity analysis (SAR), it follows that the presence of a two-carbon aliphatic linker with a carbonyl group between the thiazine and piperazine nitrogens in series 9, instead of a three-carbon (propylene) linker in series 8 , seems to be crucial for cytotoxic activity of the compounds studied (Table 3). Moreover, a fluorine substituent in the benzene ring of phenyl-piperazine moiety (compound 9c) seems to be beneficial for COX-1 inhibition activity and cancerous cells cytotoxicity. Instead, there seems to be no structure-activity relationship between structure of the new compounds and their ROS scavenging activity tested by the method applied.

However, compound 9c showed the highest therapeutic index, i.e. the largest difference between concentrations inhibiting $50 \%$ growth of normal and cancerous cells, among the compounds tested. Moreover, compound 9c also displayed a significant statistical inhibition of COX-1which may cause the inhibition of platelet activation, facilitation of immunosurveillance and prevention of haematogenous spread of malignan$\mathrm{cy}$, and has been suggested as another putative mechanism of cancer prevention (Thun et al., 2012). Additionally, compound $9 \mathrm{c}$ was very efficient at ROS scavenging under oxidative stress, which is the next important factor in the chemoprevention of cancer (Kundu et al., 2008). Such enzymes as cyclooxygenases (COX), cytochrome p450 enzymes and lipoxygenases, among others, are intercellular sources of ROS. These enzymes produce ROS as part of their normal enzymatic action and contribute to the intercellular source of ROS (Finkel, 2011). Therefore, increased COX-2 activity occurring in malignancies and inflammation, causes increased ROS levels and stimulates cancer development. Antioxidants may act by preserving normal cell cycle regulation, inhibition of proliferation and inducing apoptosis, inhibition of tumor invasion and angiogenesis, suppression of inflammation, and stimulation of phase II detoxification enzyme activity (Sen et al., 2011).

The cytotoxic activity of the new compound 9c against the LoVo cell line (colon adenocarcinoma) seems to be particularly important, as studies of recent years have proved that NSAIDs are very useful in colorectal cancer prevention (Tsioulias et al., 2015). Due to the occurrence of multidrug resistance (MDR) of colorectal cancer, further studies are needed to investigate possible capabilities of compound $\mathbf{9 c}$ to reverse this phenomenon. 


\section{Conflicts of interests}

The authors hereby declare that there are no conflicts of interests.

\section{Acknowledgments}

The authors thank prof. Kazimierz Gasiorowski for kindly reading the manuscript and offering helpful suggestion for its improvement.

\section{Acknowledgments of Financial Support}

This work was financed by the Ministry of Science and Higher Education funds for Wroclaw Medical University, project No ST-D070.17.026.

\section{REFERENCES}

AI-Fayez M, Cai H, Tunstall R, Steward WP, Gescher AJ (2006) Differential modulation of cyclooxygenase-mediated prostaglandin production by the putative cancer chemopreventive flavonoids tricin, apigenin and quercetin. Cancer Chemother Pharmacol 58: 816-825. http://dx.doi.org/10.1007/s00280-006-0228-3

Boghossian S, Hawash A (2012) Chemoprevention in colorectal cancer - where we stand and what we have learned from twenty years' experience. Surgeon 10: 43-52. https://doi.org/10.1016/j. surge.2011.07.003

Cook N, Lee I, Zhang S, Moorthy M, Buring J (2013) Alternate-day, low-dose aspirin and cancer risk: long-term observational followup of a randomized trial. Ann Intern Med 159: 77-85. https://doi. org/10.7326/0003-4819-159-2-201307160-00002

Dannenberg AJ, Altorki NK, Boyle JO, Dang Ch, Howe LR, Weksler BB, Subbaramaiah K (2001) Cyclo-oxygenase 2:a pharmacological target for the prevention of cancer. Lancet Oncol 2: 544-551. https://doi.org/10.1016/S1470-2045(01)00488-0

Dhingra AK, Chopra B, Dass R, Sanjeev, Mittal SK (2014) A review on COX and their inhibitors: Present and Future. IPP 2: 470-485

Eruslanov E, Kusmartsev S (2010) Identification of ROS using oxidized DCFDA and flow-cytometry. Met Mol Biol 594: 57-72. https://doi.org/10.1007/978-1-60761-411-1_4

Finkel T (2011) Signal transduction by reactive oxygen species. J Cell Biol 194: 7-15. doi: 10.1083/jcb.201102095

Ghosh N, Chaki R, Mandal V, Mandal SC (2010) COX-2 as a target for cancer chemotherapy. Pharmacol Rep 62: 233-244

Gravitz L (2011) First line of defence. Combinations of drugs are showing some promise as therapeutic agents that stop cancer before it starts. Nature 471: 5-7

Greenspan EJ, Madigan JP, Boardman LA, Rosenberg DW (2011) Ibuprofen inhibits activation of nuclear \{beta\}-catenin in human colon adenomas and induces the phosphorylation of GSK-3 \{beta\}. Cancer Prev Res 4: 161-171. https://doi.org/10.1158/1940-6207.CAPR-100021

Gupta RA, Dubois RN (2001) Colorectal cancer prevention and treatment by inhibition of cyclooxygenase-2. Nat Rev Cancer 1: 11-21. https://doi.org/10.1038/35094017

Harris R, Beebe-Donk J, Alshafie G (2008) Similar reductions in the risk of human colon cancer by selective and nonselective cyclooxygenase-2 (COX-2) inhibitors. BMC Cancer 8: 237. https://doi. org/10.1186/1471-2407-8-237

Kundu JK, Surh Y-J (2008) Inflammation: Gearing the journey to cancer. Mutation Res 659: 15-30. https://doi.org/10.1016/j.mrrev.2008.03.002

Krzyżak E, Szczęśniak-Sięga B, Malinka W (2014) Synthesis and thermal behaviour of new benzo-1,2-thiazine long-chain aryl-piperazine derivatives. J Therm Anal Cal 115: 793-802. doi: 10.1007/s10973013-3185-1

Lee EJ, Choi EM, Kim SR, Park JH, Kim H, Ha KS, Kim YM, Kim SS, Choe M, Kim J-I, Han JA (2007) Cyclooxygenase-2 promotes cell proliferation, migration and invasion in U2OS human osteosarcoma cells. Exp Mol Med 39: 469-476. https://doi.org/10.1038/ emm.2007.51

Loo AEK, Halliwell B (2012) Effects of hydrogen peroxide in a keratinocyte-fibroblast co-culture model of wound healing. Biochem Biophys Res Commun 423: 253-258. https://doi.org/10.1016/j. bbrc. 2012.05 .100

Lopez L, Selent J, Ortega R, Masaguer ChF, Dominguez E, Areias F, Brea J, Loza MI, Sanz F, Pastor M (2010) Synthesis, 3D-QSAR, and structural modeling of benzolactam derivatives with binding affinity for the D2 and D3 Receptors. Chem Med Chem 5: 1300-1317

Maniewska J, Szczęśniak-Sięga B, Poła A, Środa-Pomianek K, Malinka W, Michalak K (2014) The interaction of new piroxicam analogues with lipid bilayers - a calorimetric and fluorescence spectroscopic study. Acta Pol Pharm - Drug Res 71: 1004-1012

Mansouri D, McMillan D, Roxburgh C, Crighton E, Horgan P (2013) The impact of aspirin, statins and ACE-inhibitors on the presentation of colorectal neoplasia in a colorectal cancer screening programme. $\mathrm{Br} J$ Cancer 109: 249-256. https://dx.doi. org/10.1038\%2Fbjc.2013.292

Martin JE, Young GP, Leu RKL, HU Y (2013) Comparing the effects of COX and non-COX-inhibiting NSAIDs on enhancement of apoptosis and inhibition of aberrant crypt foci formation in a rat colorectal cancer model. Anticancer Res 33: 3581-3588

Muszalska I, Ciemniejewski MP, Lesniewska MA, Szkatuła D, Malinka W (2015) Forced degradation and photodegradation studies of pyrrolo[3,4-c]pyridine-1,3-dione derivatives as analgesic active compounds using HPLC, UV and IR spectrometry, and HPLC/MS methods. I $A O A C$ Inter 98: 1248-1259. https://doi.org/10.5740/ jaoacint.14-240

Park JH, McMillan DC, Horgan PG, Roxburgh CS (2014) The impact of anti-inflammatory agents on the outcome of patients with colorectal cancer. Cancer Treat Rev 40: 68-77. doi: 10.1016/j. ctrv.2013.05.006

Paudel S, Acharya S, Kim KM, Cheon SH (2016) Design, synthesis, and biological evaluation of arylpiperazine-benzylpiperidines with dual serotonin and norepinephrine reuptake inhibitory activities. Bioorg Med Chem 24: 2137-2145. doi: 10.1016/j.bmc.2016.03.044

Piazuelo E, Lanas A (2015) NSAIDS and gastrointestinal cancer. Prostaglandins other Lipid Mediat 120: 91-96. http://dx.doi.org/10.1016/j. prostaglandins.2015.06.001

Raja SB, Rajendiran V, Kasinathan NK, Amrithalakshmi P, Venkatabalasubramanian S,Murali MR, Devaraj H, Devaraj SN (2017) Differential cytotoxic activity of Quercetin on colonic cancer cells depends on ROS generation through COX-2 expression. Food Chem Toxicol 106: 92-106. http://dx.doi.org/10.1016/j.fct.2017.05.006

Romero-Canelón I, Mos M, Sadler PJ (2015) Enhancement of selectivity of an organometallic anticancer agent by redox modulation. $J$ Med Chem 58: 7874-7880. doi: 10.1021/acs.jmedchem.5b00655

Rostom A, Dube C, Lewin G, Tsertsvadze A, Barrowman N, Code C, Sampson M, Moher D (2007) Nonsteroidal anti-inflammatory drugs and cyclooxygenase-2 inhibitors for primary prevention of colorectal cancer: a systematic review prepared for the u.s. preventive services task force. Ann Intern Med 146: 376-389. doi: 10.7326/0003-4819146-5-200703060-00010

Rothwell P, Fowkes F, Belch J, Ogawa H, Warlow Ch, Meade T (2011) Effect of daily aspirin on long-term risk of death due to cancer: analysis of individual patient data from randomized trials. Lancet 377: 31-41. https://doi.org/10.1016/S0140-6736(10)62110-1

Rothwell P, Wilson M, Elwin C, Norrving B, Algra A, Warlow Ch, Meade $T$ (2010) Long-term effect of aspirin on colorectal cancer incidence and mortality: 20-year follow-up of five randomized trials. Lancet 376: 1741-1750. https://doi.org/10.1016/S01406736(10)61543-7

Sahin I, Hassan M, Garrett Ch (2014) Impact of non-steroidal antiinflammatory drugs on gastrointestinal cancers: Current state-of-the science. Cancer Lett 345: 249-257. http://dx.doi.org/10.1016/j.canlet.2013.09.001

Sen S, Chakraborty R (2011) The Role of Antioxidants in Human Health. In Oxidative Stress: Diagnostics, Prevention, and Therapy, Andreescu and Hepel eds, pp 1-37; ACS Symposium Series; American Chemical Society: Washington, DC. doi: 10.1021/bk-2011-1083. ch001

Sporn MB (1976) Approaches to prevention of epithelial cancer during the preneoplastic period. Cancer Res 36: 2699-2702

Szcześniak-Siega B, Maniewska J, Poła A, Środa-Pomianek K, Malinka W, Michalak K (2014) Synthesis of new Piroxicam derivatives and their influence on lipid bilayers. Acta Pol Pharm Drug Res 71: 10451050

Thun MJ, Jacobs EJ, Patrono C (2012) The role of aspirin in cancer prevention. Nat Rev Clin Oncol 9(5):259-267. doi: 10.1038/nrclinonc.2011.199

Tsioulias GJ, Rigas B (2015) NSAIDs and colorectal cancer control: promise and challenges. Curr Pharmacol Rep 1: 295-301. doi:10.1007/ s40495-015-0042-x

Ulrich C, Bigler J, Potter J (2006) Non-steroidal anti-inflammatory drugs for cancer prevention: promise, perils and pharmacogenetics. Nat Rev Cancer 6: 130-140. https://doi.org/10.1038/nrc1801

Wakeman Ch, Keenan J, Eteuati J, Hollington P, Eglinton T, Frizelle F (2017) Chemoprevention of colorectal neoplasia. ANZ J Surg 87: E228-E232. doi: 10.1111/ans.13392

Vane JR, Bakhle YS (2006) Cyclooxygenase 1 and 2. Annu Rev Pharmacol Toxicol 38: 97-120. https://doi.org/10.1146/annurev.pharmtox.38.1.97

Vichai V, Kirtikara K (2006) Sulforhodamine B colorimetric assay for cytotoxicity screening. Nat Protoc 1: 1112-1116. https://doi. org/10.1038/nprot.2006.179

Liao X Lochhead P, Nishihara R, Morikawa T, Kuchiba A, Yamauchi M, Imamura Y, Qian ZR, Baba Y, Shima K, Sun R, Nosho K, Mey- 
erhardt JA, Giovannucci E, Fuchs CS, Chan AT, Ogino S (2012) Aspirin use, tumor PIK3CA mutation, and colorectal-cancer survival. N Engl J Med 367: 1596-1606. doi: 10.1056/NEJMoa1207756 Yoshimura A, Koski SR, Fuchs JM, Saito A, Nemykin VN, Zhdankin VV (2015) Saccharin-based $\mu$-oxo imidoiodane: a readily available and highly reactive reagent for electrophilic amination. Chem Eur J 21: 5328-5331. doi: 10.1002/chem.201500335

Zhou B, Liu ZF, Deng GG, Chen W, Li MY, Yang LJ, Li Y, Yang XD, Zhang HB (2016) Synthesis and antitumor activity of novel Nsubstituted tetrahydro- $\beta$-carboline-imidazolium salt derivatives. Org Biom Chem 14: 9423-9430. doi: 10.1039/c6ob01495j 